\title{
PERANAN SISTEM INFORMASI MANAJEMEN BERBASIS KOMPUTER DALAM MENGAMBIL KEPUTUSAN

\author{
Muhammad Aqil
} \\ Prodi Sistem Informasi, Fakultas Sains Dan Teknologi, UINSU \\ Muhammadaqil6570@gmail.com
}

\section{$\underline{\text { Abstract }}$}

A computer-based management information system means that computers can play a very important role in a management information system. The external environment and which is closely related to technical competence, the ability of the organization to adapt to organizational success. Quality information resources on the use of management information systems are the right choice in the midst of rapid technological developments. To support the objectives, it is necessary to have a good management information system

In the use of a lot of benefits in information systems that can be utilized properly. Fast and precise information that is required in disseminating sources that are useful in achieving the expected goals. With that, it can help the benefit function in receiving information in a management role. The objectives of the institution are used in a good management information system in support of institutional goals. Of the several problems that arise as a result of several companies will be separated from various in the organization, and within the company, will cause changes so that these changes create obstacles for managers. In overcoming problems, an information system is needed to support the manager / company / organization. Management information systems in making provisions do not only require processing data into information but can transmit information to organizations / companies.

Keywords: Provisions, Systems, Information, Management, Computers. 


\begin{abstract}
$\underline{\text { Abstrak }}$
pada sebuah sistem informasi manajemen berbasis komputer dapat diartikan bahwa komputer dapat memegang peran yang sangat penting dari sebuah sistem informasi manajemen. Lingkungan eksternal dan yang berkaitan erat dengan kompetensi teknis, kemampuan organisasi untuk melakukan adaptasi pada keberhasilan organisasi. Sumber daya informasi yang berkualitas pada penggunaan sistem informasi manajemen menjadi pilihan yang tepat di tengah pesatnya perkembangan teknologi. Untuk mendukung tujuanmaka diperlukan dalam sistem informasi manajemen yang baik.

Dalam penggunaan banyak sekali manfaat pada sistem informasi yang dapat di manfaatkan sebai-baik nya. Informasi yang cepat dan tepat yang di tuntut dalam menyebar kan sumber yang bermanfaat dalam mencapai tujuan yang di harapkan. Dengan itulah dapat membantu fungsi manfaat dalam penerimaan sebuah informasi dalam peran manajemen. Tujuan lembaga yang di gunakan dalam sistem informasi manajemen yang baik dalam dukungan tujuan lembaga.Dari beberapa Masalah yang di timbulkan akibat dari beberapa perusahaan akan lepas dari berbagai di organisasi, dan di dalam perusahaan, akan menimbulajn perubahan sehingga perubahan tersebut menimbulkan hambatan bagi manajer. Dalam mengatasi persoalan-persoalan dapat di perlukan nya sebuah sistem informasi untuk mendukung manajer / perusahaan / organisasi. Sistem informasi manajemen dalam pengambilan ketentuan tidak hanya membutuhkan proses data menjadi informasi tetapi dapat menyalurkan informasi ke Organisasi / perusahaan.
\end{abstract}

Kata Kunci : Ketentuan, Sistem, Informasi, Manajemen, Komputer. 
PENDAHULUAN

Sistem informasi manajemen dalam perkembangan teknologi yang semakin maju, maka akan semakin banyak perusahaan di Indonesia dalam memanfaatkan Teknologi.

Peningkatan kinerja bagi organisasi melalui sistem informasi manajemen yang sangat besat. Persaingan pada perusahaan yang semakin berkembang karena teknologi informasi. Banyak nya penggunaan sistem yang berhubungan dari pendekatan ketentuan. Sistem informasi manajemen meneliti bahwa dalam mengambil keputusan / ketentuan merupakan salah satu indikator penting dalam keberhasilan perusahaan. Sistem informasi manajemen sudah berkembang pada teknologi informasi komputer, yang dapat di manfaatkan dalam memimpin sebuah organisasi ataupun perusahaan, dalam pengambilan ketentuan yang masih terbatas. proses yang sederhana pengambilan keputusan yang dapat di lakukan.

Komputer yang saling tersambung dari berbagai jaringan yang saling terhubung satu sama lain yang dapat di manfaatkan dalam mengambil informasi.

Karena teknologi komputer informasi tidak semua benar, komputer hanyalah temoat, yang di buat dengan mempermudah proses SIM. Prinsip kerja serta basis Sistem informasi manajemen yaitu yang berfungsi untuk sebuah manajemen, karena dari SIM lahir manajamen. Yang artinya manfaat adanya sistem informasi manajemen kepada sebuah manajemen. Proses reaksi kimiawi bukan lah zat kimia. Fungsi Manajemen yaitu untuk perancangan. Tujuan organisasi dan perusahaan dalam mengendalikan proses perencanaan, pihak manajemen berusaha dalam memikirkan apa yang harus di kerjakan, berupa ukuran ataupun jumlah yang akan di laksanakan. Di sediakan nya sistem informasi yang relavan dalam proses metode yang sudah di bentuk. Dalam penggunaan pada kinerja penggunaan alat yang dapat menyediakan sebuah informasi yang berupa sistem informasi manajemen dalam pengumpulan data dan eksternal maupun internal yang dapat menghasilkan informasi yang baik. 
Informasi ialah alat atas dasar dalam pemimpin organisasi serta manajer atas membuat motode, yang dapat di rumuskan dalam kegiatan ataupun ketentuan.

Dalama manajemen pengambilan keputusan bagi kunci komponen yang merupakan variabel yang bersumber dari sistem informasi dalam peranan manajemen. Sistem informasi manajemen yang sangat penting fan berperan dalam berbasis komputer.

\section{STUDI LITERATUR}

Studi literatur yang mana sudah saya kerjakan yaitu dengan bentuk mengangkat beberapa informasi dari jurnal, buku, makalah, karya tulis maupun scripsi tujuan nya untuk membahas tentang Sistem Informasi Manajamen sebagai konsep "Peranan Sistem Informasi Manajemen Berbasis Komputer Dalam Mengambil Keputusan ”.

\section{METODE PENELITIAN}

Motode dalam menggunakan komputer pada kegiatan penerapan sistem informasi manajemen. Jika tanpa adanya komputer mungkin sistem informasi manajemen tidak akan berjalan dengan lancar. Dalam pengelolaan informasi berbasis pada komputer yang digunakan dndgan akurat dan juga se efektif mungkin Dalam proses mengambil keputusan / ketentuan pada sistem berbasis komputer yang dapat di sesuaikan dnegan yang di gunakan oleh eksklusif dalam pembuat putusan. Sistem informasi manajemen yang menghasilkan perkembangan pada perangkat lunak yang memengaruhi kualitas sistem.

a. sistem

Perbandingan bahan / definis yang dapat diambil dari sistem yaitu :

Untuk mencapai tujuan bersama-sama sistem salah satu kesatuan dalam komponen yang snagat jelas dalam melakukan aktivitas.

\section{b. Informasii}

Resiko yang paling kecil dengan tindakan-tindakan dam memilih informasi dengan adanya putusan mempunyai nilai serta mengurangi tidak benarnya dalam sistem 
informasi. Maka proses yang telas di siapkan dengan matang. Sehingga menjadi Informasi. Masalah yang di hadapi perusahan dalam kebijakan mengambil keputusan yang baik dapat di perlukan pengelolan data menjadi informasi yang akurat.

\section{c. Sebuah Sistem Informasi}

Kebutuhan yang serupa dam pemakaian beberapa bagian informasi yang dapat menyediakan sebuah informasi di dalam komputer yang di definisikan sebagai sistem yang sederhana. Organisasi dalam informasi yang penting dalam mengenai orang maupun tempat lingkungan sekitar . Dalam mengambil keputusan sendiri mengandung suatu arti adalah data yang di kelolah dalam sebuah bentuk informasi. Di dalam lingkungan fisik Organisasi sendiri merupakan kebenaran-kebenaran atas mewakili sebuah kedaan ataupun kondisi atau sebuah peristiwa yang terjadi. Pengambilan keputusan dapat dimanfaatkan atau di gunakan dalam memhamai sistem. SIM mengandung tiga tugas dalam aktifitas di dalam nya adalah :

- memasukkan input

- proses

- pengeluaran outpun

Tiga tugas di atas adalah dasar yang di hasil kan informasi yang di butuhkan dalam sebuah organisasi dalam mengambil ketentuan, pengendalian, operasi, masalah, yang dapat menciptakan alat baru.

\section{d. Manajemen}

Kegiatan yang dapat di pergukanan dalam yang di tetap kan dalam pencapaian tujuan pada manajamen. Perusahaan dan organisasi dalam kamus besar bahasa Indonesia yaitu penggunaan secara baik untuk mendapatkan tujuan pemimpin dan menjalan kan nya.

Dapat di definisikan tiga bagian.

1. Adanya tujuan yang mau di capai

2. Adanya tujuan dalam membutuhkan tenaga kerja

3. Adanya kegiatan manusia yang harus membimbing serta mengawasinya yang dapat mengontrol nya. 


\section{e. Komputer}

Simbol-simbol yang baik berupa angka, kode huruf yang dapat dikelola dalam sebuah alat komputer. Analog serta digital yang dimasukkan Manusia di di dalam komputer yaitu simbol- simbol melalui alat input, yang dapat mengelolanya. Proses kombinasi antara komponen perangkat lunak, perangkat keras, serta komunikasi dan sumber daya manusia dan sistem informasi melalui protokol-protokol yang telah di tentukan.

Dalam ke lima komponen yang sudah di jelaskan diatas tidak dapat berdiri sendiri. Dikarenakan hardware yang dapat memproses pneggajian contoh : adanya program perangkat lunak / keras, yang sedemikian pula sebaliknya perangkat lunak atau program pada komputer yang dapat membuat informasi - informasi yang di butuhkan dalam perangkat keras dengan di melengkapi tugas yang di perlukan / digunakan. Dalam pengelolaan data menjadi informasi dalam konsep sistem informasi tradisional. Merupakan komponen utama dari manusia dan komputer yang menjalankan nya. Sistem yang di olah oleh manusia yang dapat menerima masukan serta menghasilkan keluaran yaitu keterbatasan. Sistem menyediakan banyak masukan. Dalam proses penyaringan dan seleksi manusia dalam mengurangi masukan dala jumlah dengan batas yang di tentukan. Menyelesaikan konflik atau pertentangan dnegan mengambil keputusan yaitu suatu proses pemilihan di berbagai alternatif baik dari kualitatif maupun kuantitatif sebagi mendapat kan sebuah jalan alternatif mudah yang baik untuk di gunakan dalam menjawab. Ada empat unsur yang terkandung pada proses penurunan :

1) Kualitatif atau kuantitatif merupakan model menunjukkan gambaran sebuah masalah

2) Keputusan yang diambil perlu di diskusikan / di rumuskan menunjukkan tujuan keputusan diamtril. Jika dapat beberapa kriteria yang bertentangan, maka pengambilan ktentuan harus melalui diskusi/kompromi contoh mengurangi persediaan. 
3) Dana yang kurang tersedia faktorfaktor tambhaan yang perlu di liat dari memecahkan permasalahan dalam mengambil keputusan.

4) Mengembangkan

kegiatan ketentuan sudah dapat dilihat secara detail metode, yang di gunakan untuk menentukan apa yang di perlukan perbandingan yang di diizinkan.pada kegiatan proses mengambil keputusan dalam pemecahan terbaik fan optimal.

Ada tigas Strategi dalam mengambil keputusan yaitu :

(1). Pengumpulan keputusan tingkat cara dalam mengambil putusan, cara yang cirinya berjumlah besar dan tidak pasti mengarah ke masa depan. Putusan-putusan dalam menentukan metode jangka panjang akan mempengaruhi keseluruhan organisasi.

(2) untuk mencapai tujuan keputusan tingkat taktis dalam pengambilan putusan yang berhubungan dalam aktivitas jangka pendek dan mentukan sumber daya dalam mengambil putusan.
(3) Efektif dan efisien dalam tingkat teknis. Pada tingkatan standar, dapat di tentukan output nya yang bersifat deterministik atau sifat yang menentukan. Di dalam mengambil putusan tekni yaitu sebuah proses yang di jamin bahwa tugas spesifik dapat terlaksana dalam pengambilan keputusan.

Perencanaan ini lebih sedikit dari fungsi Menekankan. Dilaksakan nya pada tingkat pengambil6 Keputusan dalam program yang dilakukan contoh jenis pengambilan ketentuan terprogram dapat di jalankan.

Penetapan pada tenaga kerja yaitu dan penerimaan ataupun penolokan kredit, pengendalian proses, waktu, menerima, mengirim, mengawas inventaris merupakan jenis pengambilan keputusan.

\section{HASIL PEMBAHASAN}

Kegiatan dam melakukan organisasi untuk menghadirkan komputer dalam sistem informasi manajemen yang telah memebrrikan banyak dalam kemudahan pada manajer karena ada nya teknologi informasi. Bagi perusahaan yang sangat memerlukan 
perangkat keras hanya merupakan salah satu sumber daya fisik yang dapat berfungsi tanpa ada Manusia yang dapat memberikan instruksi metupaja prinsip komputer. Pada operasional manusia dapat membuat teknologi yang bernama perangkat lunak "software" yang dsarnua merupakan suatu urutan instruksi untuk dapat "menggerakan" sebagi komponen ok erangkan keras.Ada dua jenis sofware perangkat lunak yaktu: sistem sofware yang dapat berisi perintah jnyuk menjalankan sebuah proses tertentu yang dikenal sebagai Application software. Alat yang digunakan dalam mengelola data yang di definisikan sebagai komputer yang di kenal kan pada abad yang lalu. Yang di pergunakan secara umum sampai saat ini. Input yang di berikan dengan mengutamakan metode " input, dan output" dalam lengunaan bagi seorang yang dapat menghasilkan output tertentu merupakan prinsip-prinsip IPO.

Apabila dalam bentuk proses hanya spesifik dalam hal semacam perhitungan kuantitatif, di dalam perkembangan pada saat ini pa sebuah proses komputer sudah Dapat berfungsi dalam kehidupan manusia seperti contoh dalam proses belajar, komunikasi, mencari informasi, perdagangan dan lain-lain. Kelompok di bagi menjadi dua perusahaan yang memproduksi informasi, dengan teknologi hubungan yang bertujugas dan manajer dan perusahaan.

Teknologi informasi yang dimiliki dam pengumpulan dari Meraka yang merupakan pengguna kolompok pertama. di dalam ini seluruh jenjang produksi dari staf sampai pemimpin puncak termasuk dalalm kelompok. Aktivitas dalam penunjang dan mendukung pekerjaan sehari hari dalam menggunakan teknologi informasi.

Di dalam kelompok ini mereka dapat bertanggung jawab atas metode dan pengembangan teknologi informasi oada perusahaan. Tugas utama terdapat ada beberapa metode yaitu :

1. Mengatur metode cara rencana induk mengenai pengembangan pada sistem dan juga teknologi informasi pada lembaga.

2. Dapat di definisikan secara perinci dalam kepentingan oaf sebuah sistem informasi pada perusahaanperusahaan, yang Merupakan 
bentuk spesisfik dari berbagai individu.

3. Dan di definisikan teknologi ok ada sistem informasi yang sesuai dengan yang di manfaat atau di butuhkan.

4. Meningkat Teknologi pada sistem informasi yang di perintah oleh perusahaan agar falay selalu mancari informasi terbaru dan dapat digunakan pada sebuah produksi perusahaan.

5. Pengembangan teknologi merupakan pada pihak perusahaan yang bekerja sama dnegan mengelola hubungan kemitraan.

6. Mengecek serta mengawasi sebuah proses pengelolaan pada aset teknologi informasi.

Dalam mempin rangkaian tugas, pada dasarnya di kenal sebagai jabatan professional, contoh chief, office, executi information, manager dan teknologi system analyst, program atau projek dalam manager tiap-tiap memiliki keahlian khusus yang berhubungan dengan teknologi informasi. Peranan sistem informasi manajemen yang berbasis kan komputer merupakan suatu nilai keputusan informasi yang berhubungan perusahaan. Komputer maupun non komputer merupakan pada pembuatan keputusan ok ada suatu organisasi / lembaga dapat di uraikan dengan 3 bagian tahapan dalam proses pengambilan keputusan dengan dukungan sistem informasi.

Sistem informasi manajemen yaitu sebuah proses dan menyelidiki suatu kasus pemeriksaan data dengan baik secara yang telah di tentukan ataupun cara khusus. Perhatian dalam kedua cara sistem informasi yang harus di teliti semua data untuk mengajukan permintaan untuk dapat di uji merupakan sebuah SIM. Kemungkinan pada sebuah organisasi harus mrmiki saluran komunikasi untuk mengetahui suatu permasalahan di ketahui dengan jelas agar dapat di smapaikan atau di benar kan kepada organisasi dan permalasahan itu dapat di tangani. Permasalahan yang memerlukan data base dan data masyarakat, merupakan persaingan dan di tambah dengan metode dalam penelitian maupun penemuan yang di dukung oleh SIM. Alternatif dalam sebuah rancangan yang berkaitan dengan sistem informasi manajemen yaitu metode-metidd dalam Keputusan yang daoat di olah menggunakan dta serta 
menyelesaikan pemecahan pada tahap perancangan. Metode-metode yang tersedia harus mambabtu dalam analisis penggantian. Dari dukungan sistem informasi manajemen yang terdiri dari perangkat lunak dalam pembentukan metode lainnya. Data base dalam pendekatan stuktur dapat memanipulasi metode dan sistem pencarian yang dapat melibatkan sistem. Dalam mengambil keputusan sistem informasi manajemen snagat efektif karena hasil-hasil dalam perancangan daoat di sajikan dalam bentuk data. Kemudian jika dilakukan pilihan dalam peranan sistem informasi manajemen yang dapat merubah menjadi pengumpulan informasi yang sangat baik. Pemilihan prosedur / proses yang dapat di tentukan pada tahap pemilikan yaitu memilih berbagai metode dalam Keputusan yang memerlukan penyelidikan (analisis) dalan kesepakatan ataupun menentukan proses yang di dukung oleh SIM. Metode-metode dalam pembuatan perangkat lunak yang berisi metode dasar pada suatu pembuat keputusan yang lengkap dalam kemampuannya mencari data base, perangkat lunak dana analitik lainnya yang di dukung oleh SIM. Keputusan yang berulang merupaka strategi jangka panjang apabila tidak ada pilihan dalam keputusan, informasi yang tidak di perlukan. Dalam efektifitas yang bernilai apabila manfaat yang lebih efekti6 dibandingkan dari biaya dalam mendapatkan sebagian besar informasi yang tidak dapat dihitung keuntungan nya dengan satuan niaki uang yang merupakan suatu tujuan informasi. Cost ataupun cost benefit dapat dikatakan bahwa nilai pada sebuah sistem pengukuran nilai yang akan lebih tepat dalam penggunaan nya.

\section{KESIMPULAN}

Dapat disimpulkan dari pembahsan diatas dalam pengendalian Keputusan dan pengendalian dalam yang mendukung untuk menghasilkan informasi dalam menunjang seperangkat prosedur ataupun alat yang ada pada sistem informasi manajemen.

Pengembalian keputusan berbasis komputer sangat mendukung untuk memabangun sistem informasi manajemen. Tugas-tugas pelaksanaan dalam rangka yang sedang 
berlangsung proses-proses pada penting nya bagi perusahaan dalam mengambil keputusan berbasis komputer pada sistem informasi manajemen. Telah di kelola dan di koordinasikan manajemen dan di rancang melalui sistem dan prosesproses bisnis yang dapat menentukan perusahaan bagi kinerjanya, sedangkan dam meningkatkan kinerja perusahaan dapat di bangun di dalam sistem informasi manajemen. Manajemen fungsional Merupakan salah satu bidang yang hanya di yang tidak dapat di selesaikan pada perusahaan dengan bantuan sistem informasi manajemen berbasis komputer sangat mendukung dan mempermudah bagi perusahaan.

Pemanfaatan berkas dan file-file manual yang ada di dalam basis komputer baik itu proses-proses yang bisa mendukung pilihan dalam merancang intelejensi adalah dam mengambil keputusan berbasis komputer yang sangat mendukung.

Pertanggung jawabakan awaban yang telah dijekaskan diatas bahwa muncul nya teknologi komputer yang membawak dampak positif dalam sistem informasi manajemen yang sangat dimanfaatkan para pemimpin perusahaan ataupun organisasi dala mengambil keputusan yang baik dan benar. Yang dapat di pertanggung jawabkan atas kehadiran komputer dalam sistem informasi manajemen bukan hanya memberikan manfaat positif tetapi jauh dari itu dalam proses pengambilan putusan akan sangat lebih mudah. Teknologi informasi dalam bidang kremajuan di dalam nya termasuk ilmu pengetahuan.

Keunggulan kompetitif yang dapat meraih apabila ingin melakukannya kebijakan-kebijakan dalam pengambilan keputusan yang memiliki akurasi yang cukup tinggi pada suatu perusahaan.

Keunggulan yang dapat menguasai bagi siapapun menjadi penting pada sebuah informasi. Manajer yang memakai sumber daya yang salah satunya informasi. Saat ini kemampuan komputer sejalan dengan matangnya pengelolaan informasi.

Perumusan daam seseorang manajer terutama nya dalam pengambilan keputusan. Dalam melakukan tugas secara efektif dan efesien dapat di lakukan dengan cepat dan mudah yang di dukung oleh sistem informasi 
berbasis komputer. Informasi dan komputer tentang pengetahuan dalam pemecahan masalah dalam bidang komunikasi hal ini terwujud karena aja nya manajer yang memlin perusahaan dengan baik menggukan sistem informasi berbasis komputer.

Dan dapat di simpulkan bahwa dalam mengambil keputusan yaitu :

1. Hadirnya komputer dalam mengambil keputusan yaitu pengembangan yang telah hadir pada sistem informasi.

2. Dapat di pertanggung jawabkan bagi para pemimpin maupun perusahaan dalam mengambil keputusan sistem informasi manajemen

3. Teknologi komputer meniliki perkembangan yang cukup pesat di dunia sehingga dapat dimanfaatkan untuk SIM

4. Tidak ada basa basi dalam pengambilan keputusan yang dapat dibutuhkan pada sebuah perusahaan dapat di sajikan manfaat, yang bernilai dan juga berkualitas, yaitu informasi yang efektif pada sebuah sistem informasi manajemen berbasis komputer.
5. Penyimpanan secara manual berbasis komputer yang dapat menyimpan semua arsip-arsip maupun dokumen yang dapat di lakukan dari para Manajer agar dapat menghasilkan informasi yang efektif dan juga efesien dari pada sebelumnya pada sbeuah Sistem informasi manajemen.

6. Secara digital dalam menyimpan secara cepat dan juga proses dalam pencarian tidak membutuhkan waktu yang lama, karena adanya sistem informasi manajemen berbasis komputer.

Fungsi manajemen berbasis komputer ini, yang memudahkan perusahaan, manajer, atau Organisasi dapat memilih waktu yang lebih mudah, efesien, efektif, dalam mengambil keputusan yang di lakukan oleh SIM. Dan dapat di pertanggung jawabkan dalam penggerakan aktuating, serta pengawasan yang di hasil kan keputusan pada perancangan planning.

\section{DAFTAR PUSTAKA}

Azhar Susanto, 2004. Sistem informasi manajemen. Bandung Linggar haya. 
Hartino, jogiyanto. 2000.

Pengenalan komputer: dasar Ilmu

Komputer, Program, Sistem Informasi, dan intelegnsi buatan.

Edisi 3, Cet. Kedua. Yogyakarta: Andi.

Stubri, Tata. 2012. Analisis sistem informasi. Yogyakarta: Andi.

G.-H. Tzeng dan J. J Huang, Metode Pengambilan Keputusan Dan Aplikasi Beberapa Atribut. GRC Press, 2011.

Suryaputri, Rosje V dan Adi Widijanarko. 2012 Analisis Faktorfaktor Yang Mempengaruhi Minat Pemanfaatan Sistem Informasi Dan Penggunaan Sistem Informasi. (Studi Empiris pada staff administrasi politeknik Negeri Sriwijaya). Seminar Nasional Ilmu Komputer (SNIK 2015), Semarang. 10 Oktober 2015. iSBN:2302-3805.

Putra, Yamanto Mihadi. 2018. Modul Kuliah Sistem Informasi dalam Mengambil Keputusan. FebUniversitas Mercu buana: Jakarta.

E.S Marhianti, D. Suryadi H.S. Sistem Informasi Manajemen, Gunadarma, 1094 Hall 1996.
Rohmat Taufiq, ST.,M.Kom. 2013.

Sistem Informasi Manajemen,

Konsep Dasar, Analisis dan Metode

Pengembangan. Graha Ilmu.

Yogyakarta.

Antmousdirjo, $2012 \quad$ Sistem Informasi Manajemen. Jakarta : STIA-Lembaga Administrasi Niaga Cipta.

Sunyoto, Danang, 2914. Sistem Informasi Manajemen, Prepektif Organisasi, CAPS (Center Of Academic Publishing Service), Yogyakarta. 